\title{
PERAN GURU DALAM MENGEMBANGKAN KETERAMPILAN BAHASA SISWA MELALUI KEGIATAN LITERASI DI KELAS 04 SD INPRES SANGIANG
}

\author{
Rahni \\ Prodi PGMI Institut Agama Islam (IAI) Muhammadiyah Bima \\ Email: rahnyjunaidin@gmail.com
}

\begin{abstract}
Abstrak
Penelitian ini berjudul Peran Guru dalam Mengembangkan Keterampilan Bahasa Siswa Melalui Kegiatan Literasi di Kelas 04 SD Inpres sangiang Tahun Ajaran 2019/2020. Dalam proses pengajaran guru memiliki peran penting dalam membentuk keterampilan bahasa guna mengoptimalkan perkembangan keterampilan bahasa siswa. Namun sangat disayangkan kemampuan bahasa anak Indonesia masih sangat rendah, siswa di kelas tinggi khususnya di kelas 04 memiliki berbagai keanekaragaman dalam keterampilan bahasa. Faktor ini dipengaruhi oleh perbedaan latar belakang siswa, minimnya perbendaharaan kata pada siswa prasekolah, penggunaan dua bahasa di lingkungan keluarga, terbatasnya kemampuan siswa kelas 04 dalam memahami konteks bacaan. Metode yang digunakan dalam penelitian ini adalah deskriptif kualitatif dengan menggunakan teknik pengumpulan data berupa observasi, wawancara, dan dokumentasi.Pemeriksaan keabsahan data menggunakan triangulasi. Data dianalisis melalui langkahlangkah pengumpulan data, reduksi data, penyajian data, dan penarikan simpulan. Responden pada penelitian ini berjumlah 3 orang yakni guru kelas, guru kelas dan guru perpustakaan. Hasil temuan dalam penelitian ini menunjukkan bahwa guru kelas 04 sudah menjalankan perannya sebagai fasilitator, demonstrator, motivator, pengelola kelas, dan evaluator dengan optimal melalui kegiatan literasi diantaranya adalah kegiatan pojok membaca, dan kunjungan perpustakaan untuk mengembangkan keterampilan bahasa siswa. Dan siswa kelas 04 SD inpres sangiang secara umum sudah menunjukkan perkembangan keterampilan bahasa yang baik, dapat dilihat dari daftar ceklis yang di buat oleh guru.

Kata Kunci: Peran Guru, Keterampilan Bahasa, Literasi
\end{abstract}

\section{PENDAHULUAN}

Kehidupan bangsa yang cerdas adalah kehidupan bangsa dalam segala sektornya, politik, ekonomi, keamanan, kesehatan, dan sebagainya, yang makin menjadi kuat dan berkembang dalam memberikan keadilan dan kemakmuran bagi setiap warga Negara (Nur Azizah, 2018). Sehingga mampu menghadapi gejolak apapun, baik yang bersifat domestik maupun internasional. 
Dalam proses pengajaran guru memiliki peran penting dalam membentuk keterampilan bahasa guna mengoptimalkan perkembangan bahasa siswa. Keterampilan bahasa siswa akan mempengaruhi perkembangan kognitif, sosialdan emosional siswa sebagai penunjang keberhasilan pembelajaran diberbagaibidang. Oleh karena itu, sangat penting bagi siswa terutama ditingkat sekolah dasar untuk memperoleh pembelajaran keterampilan bahasa secara maksimal. Keterampilan bahasa siswa dapat diwujudkan melalui kegiatan literasi, karena kegiatan literasi memiliki peranan penting terhadap kesuksesan belajar siswa.

Sejalan dengan pendapat yang dikatakan Piaget, bahwa bahasa mempunyai kemampuan yang lebih dalam mengembangkan pemikiran dibandingkan aspek sensorimotor yang berjalan lebih lambat dibandingkan inteligensi yang digerakan oleh bahasa. Dapat diartikan bahwa aktivitas intelegensi anak akan berkembang lebih cepat dengan adanya bahasa (Nur Azizah, 2018).

Namun sangat disayangkan kemampuan bahasa anak Indonesia masih sangat rendah, berdasarkan studi yang dilakukan oleh Program forInternational Student Assessment (PISA). Aspek yang diteliti PISA adalahkemampuan membaca, matematika, dan sains. Kemampuan membaca siswa Indonesia 80\% masih berada dilevel 1, level 2, dan di bawah level 1 yang berarti sebagian besar masih di bawah standar internasional.

Berdasarkan hasil observasi yang dilakukan oleh peneliti ketika pelaksanaan Penelitian Praktik Lapangan (PPL), peneliti mengamati siswa di kelas awal khususnya di kelas 04 memiliki berbagai keanekaragaman dalam keterampilan bahasa. Faktor ini dipengaruhi oleh perbedaan latar belakang siswa, minimnya perbendaharaan kata pada siswa prasekolah, penggunaan dua bahasa dilingkungan keluarga, terbatasnya kemampuan siswa kelas 04 dalam memahami konteks bacaan. Oleh karena itu, membangkitkan keterampilan bahasa menjadi salah satu persoalan penting untuk mengetahui perkembangan bahasa siswa. Berangkat dari keprihatinan tersebut, sekolah SD Inpres Sangiang menggalakkan kegiatan literasi dengan tetap memperhatikan segala aspek sesuai kebutuhansiswa. Kelas 04 adalah kelas yang paling tepat 
untuk memperkenalkan,mengajarkan, dan mananamkan budaya dan nilaimelalui kegiatan literasi yangbertujuan untuk mengembangkan keterampilan bahasa siswa (Rismah, 2019).

Peran guru kelas dalam menjalankan kegiatan literasi untuk mencapai tujuan keterampilan bahasa menjadi tanggung jawab yang luar biasa di sekolah SD Inpres Sangiang, mulai dari menyiapkan media literasi, memfasilitasi kegiatan literasi sampai menjalankan kegiatan literasi. Peran guru sebagai pengajar, pendidik, dan pembimbing menjadi sangat dominan karena usia siswa kelas 04 adalah usia operasional konkret di mana pada usia tersebut siswa memperoleh kemampuan berbahasa dengan kegiatan yang langsung didemosntrasikan oleh guru baik secara verbal, visual dan menggunakan media konkret dalam proses pembelajarannya. Peran tersebut yang akan mempengaruhi perkembangan bahasa siswa.

Kegiatan literasi anak juga sangat membutuhkan kinerja atau kesiapan guru disini peran guru sebagai fasilitator, pengarah dan motivator dalam perkembangan literasi anak usia dini mampu memberikan dampak yang, signifikan pada perkembangan literasi anak. Menurut Saya, Anak yang sudah menguasai kemampuan literasi sejak dini akan menyebabkan anak menjadi seorang pembelajar sepanjang hidupnya.Oleh karena itu, mengembangkan kegiatan literasi harus dilakukan secara sistematis artinya terencana, berkelanjutan atau terus menerus. Peran orang dewasa sangat diperlukan untuk tercapainya tujuan dari kegiatan literasi, dalam konteks ini guru sebagai orang dewasa yang berada dekat dengan anak di sekolah menjadi figur yang mampu mengarahkan, memotivasi dan menanamkan kebiasaan literasi di sekolah.

Berdasarkan latar belakang masalah tersebut, maka penulis beranggapan bahwa Peran Guru dalam Mengembangkan Keterampilan Bahasa Siswa Melalui Kegiatan Literasi di Kelas 04 SD Inpres Sangiang layak untuk diteliti dan dikembangkan secara ilmiah. 


\section{TINJAUAN TEORITIS}

\section{Peran Guru}

Guru adalah salah satu factor yang menentukan mutu pendidikan. Gurulah yang berada di garda terdepan dalam menciptakan kualitas sumber daya manusia. Guru berhadapan langsung dengan peserta didik di kelas melalui proses belajr mengajar. Ditangan gurulah akan dihasilkan peserta didik yang berkualitas, baik secara akademis, skill (keahlian), kematangan emosional, moral, dan spiritual. Dengan demikian, akan dihasilkan generasi masa depan yang siap hidup dengan tantangan zamannya. Oleh karena itu, diperlukan yang memiliki syaratsyarat, kompetensi dan dedikasi yang tinggi dalam menjalankan tugasnya (St. Marwiyah, 2012).

Secara umum, ada tiga tugas guru sebagai profesi, yakni mendidik, mengajar dan melatih. Mendidik berarti meneruskan dan mengembangkan nilai-nilai hidup, mengajar berarti meneruskan dan mengembangkan ilmu pengetahuan, melatih berarti mengembangkan keterampilan-keterampilan untuk kehidupan siswa. Untuk dapat melaksanakan tugas dan tanggung jawab diatas, seorang guru dituntut untuk memiliki beberapa kemampuan dan kompetensi tertentu sebagai bagian dari profesionalisme guru

1. Untuk merealisasikan hakekat mengajar yang sesungguhnya di sekolah, guru harus memiliki pengetahuan/bidang ilmu yang diajarkan secara luas dan mendalam, itikad yang baik dalam membagi ilmu pengetahuan yang dimiliki dengan siswa, dan komitmen untuk terus belajar sepanjang hayat (Suyanto dan Asep Jihad, 2013).

Agar guru dapat melaksanakan tugasnya dengan baik dalam mengajar, maka mereka dituntut dalam hal :

a. Kemampuan merumuskan tujuan pembelajaran

b. Penguasaan prinsip belajar mengajar

c. Penguasaan sumber belajar

d. Penguasaan pendekatan, metode dan tekhnik belajar mengajar

e. Kemampuan menggunakan sarana belajar dengan baik

f. Kemampuan mendorong siswa untuk belajar secara aktif

g. Kemampuan penguasaan bahan ajar 
h. Kemampuan mengelola kelas

i. Mengelola program belajar mengajar

j. Kemampuan menggunakan media (Sardiman AM, 2004).

2. Mendidik

Mendidik adalah kegiatan guru dalam memberi contoh, tuntunan, petunjuk dan keteladanan yang dapat ditiru oleh peserta didik dalam kehidupan sehari-hari. Agar peranan mendidik ini dapat berjalan dengan baik, maka seorang guru dituntut untuk :

a. Mampu merumuskan tujuan yang ingin dicapai

b. Memahami dan menghayati tugas profesi sebagai guru

c. Mampu menjadi teladan yang baik

d. Mampu menjadi orang tua di sekolah

e. Memiliki sifat terpuji dan menjauhi sifat tercela (W. Gulo, 2004).

3. Pembimbing

Sebagai pembimbing guru memiliki peranan dalam memberikan bimbingan kepada peserta didik yang mengalami masalah-masalah terutama yang sifatnya non akademis, karena itu guru harus menjadi model, sebab tidak mungkin guru dapat menjalankan perannya sebagai pembimbing apabila mereka tidak memiliki kepribadian yang baik. Misalnya guru sulit merubah perilaku siswa yang tidak disiplin, apabila mereka tidak memberi contoh disiplin terlebih dahulu.

\section{Keterampilan Bahasa}

Keterampilan menurut KBBI adalah kecakapan untuk menyelesaikan tugas, dengan benar. Jadi dapat disimpulkan bahwa keterampilan adalah kecekatan, kemampuan, kepandaian, kemahiran seseorang dalam mengerjakan kegiatan atau tugas dengan baik (An. KBBI, 2018).

Dalam kehidupan sehari-hari, dapat dipastikan, seluruh aktifitas manusia tidak terlepas dari bahasa. bahasa juga digunakana oleh manusia sebagai media untuk menyampaikan informasih, pikiran, dan perasaan pada orang lain. Dengan bahasalah manusia bisa mengungkapkan perasaan, menjalin hubungan dengan orang lain,dan juga digunakan untuk mempengaruhi orang lain. Bahasa dengan manusia, pada giliranya 
menjadi hal yang menyatu karena bahasa adalah media yang paling representatif dalam mengemas ide untuk disampaikan pada orang lain. Bahasa yang dimaksud, tentunya,adalah bahasa verbal,baik lisan maupun tulisan. Bahasa juga adalah sistem lambang bunyi yang dihasilkan oleh ucap manusia yang berfungsi untuk komunikasih antara anggota yang satu dengan anggota yang lainya (Abdul Wachid B.S, \& Heru Kurniawan, 2013).

Keterampilan bahasa bertujuan untuk meningkatkan nilai mata pelajaran yang khususnya pelajaran bahasa indonesia, menambah kosakata dalam berbahasa, menambaha wawasan dan informasih baru, meningkatkan informasih siswa dan menulis dan merangkai katakata,dan menumbuhkan kreatifitas siwa dalam berfikir dan berbicara (Nur Salim AR, 2011).

Upaya Optimalisasi Perkembangan Bahasa Anak Usia SD sebagai berikut :

1. Menyeimbangkan aspek-aspek keterampilan berbahasa, yaitu mendengarkan, berbicara,membaca,dan menulis.

2. Anak perlu melakukan pengulangan dengan menceritakan kembali pelajaran yang telah diberikan dengan menggunakan bahasa sendiri.

3. Berdasarkan hasil identifikasi guru melakukan pengembangan bahasa murid dengan menambahkan pembendaharaan kata dalam bahasa dan lingkungan yang dipilih oleh guru dan harus tepat dan benar.

4. Dengan menggunakan model pengekspresian secara mandiri, baik lisan maupun tertulis. Dengan berdasarkan pada bahan bacaan akan lebih mengembangkan kemampuan bahasa anak dan membentuk pola masing-masing anak (Nur Azizah, 2018).

Keterampilan berbahasa ( language arts, language skill ) dalam kurikulum disekolah biasanya mencakup empat segi, yaitu:

1. Keterampilan Menyimak

Ialah suatu aktivitas yang mengcakup kegiatan mendengarkan, dan bunyi bahasa mengidentifikasih, menginterprestasi, menilai dan merealisasi atas makna yang terkandung dalam bahasa simakan.

2. Keterampilan Berbicara 
Merupakan suatu proses berkomunikasih sebab didalamnya terjadi pemindahan pesan dari suatu sumber ke tempat lain,dan berbicara menyampaikan pesan melalui bahasa lisan. Untuk mencapai tujuan keterampilan berbicara di kelas awal guru hendaknya meminta siswa untuk menceritakan kemballi pegalaman, menceritakan kembali cerita yang pernah dibaca atau di dengar, mengungkapkan mengalaman pribadi, bertanya jawab berdasarkan bacaan, bermain peran, berpidato, dan bercakap-cakap.

3. Keterampilan Membaca

Membaca ialah suatu cara untuk mendapatkan informasih dari sesuatu yang ditulis.pengertian lain dari membaca merupakan suatu proses tranksaksi yang didalamya pembaca cerita mengartikan maksud yang dibuat penulis.

4. Keterampilan Menulis

Menulis merupakan suatu proses kreatifitas menuangkan gagasan ataupun ide yang ada didalam pikiran kedalam bentuk tulisan dengan tujuan tertentu.

\section{Literasi}

Jadi, literasi dapat diartikan sebagai kemampuan mengarahkan semua informasih yang telah didapat dengan cara memahami informasih dan berfikir kritis.seseorang diri.

1. Membaca

Pengertian Membaca adalah suatu cara untuk mendapatkan informasi dari sesuatu yang ditulis. Adapun pengertian lain dari membaca adalah suatu proses transaksi yang didalamnya pembaca cerita mengartikan maksud yang dibuat penulis. Membaca adalah suatu proses yang dilakukan serta dipergunakan oleh pembaca untuk memperoleh pesan, yang hendak disampaikan oleh penulis melalui media kata-kata/bahasa tulis, Membaca dapat diartikan sebagai suatu metode yang kita pergunakan untuk berkomunikasi dengan diri kita sendiri dan kadang-kadang dengan orang lain, yaitu mengomunikasikan makna yang terkandung atau tersirat pada lambang lambang tertulis (Henry Guntur Tarigan, 2008).

2. Pengertian Menulis 
Menulis merupakan suatu proses kreatifitas menuangkan gagasan ataupun ide yang ada didalam pikiran kedalam bentuk tulisan dengan tujuan tertentu. Menulis adalah suatu bentuk berfikir dimana yang dituangkan dalam kata-kata yang lebih mudah dipahami dan mudah dimengerti. Dalam kehidupan modern ini, jelas bahwa keterampilan menulis sangat dibutuhkan.kiranya tidak terlalu berlebihan bila kita katakana bahwa keterampilan menulis merupakan suatu ciri dari orang yang terpelajar atau bangsa yang terpelajar.

Terdapat dua tujuan literasi yaitu secara umum dan secara khusus. Tujuan literasi secara umum ialah menumbuh kembangkan budi pekerti siswa melalui pembudidayaan ekosistem sekolah agar mereka menjadi pembelajaran sepanjang hayat. Secara khusus tujuan literasi sebagai berikut:

1. Menumbuhkan dan mengembangkan budaya literasi sekolah.

2. Meningkatkan kapasitas warga dan lingkungan sekolah agar literat.

3. Menjadikan sekolah jadi taman belajar yang ramah dan nyaman agar warga sekolah mampu mengelola pengetahuan

4. Menjaga keberlanjutan pembelajaran dengan menghadirkan beragam buku di sekolah dan mewadahi berbagai strategi membaca.

Jadi, literasi dapat diartikan sebagai kemampuan mengerahkan semua informasi yang telah didapat dengan cara memahami informasi dan berfikir kritis Seseorang dapat dikatakan literat jika sudah bisa memahami sesuatu kerena membaca informasi yang tepat dan melakukan sesuatu berdasarkan pemahamannya terhadap isi bacaan.

\section{METODOLOGI PENELITIAN}

Jenis penelitian yang digunakan oleh peneliti dalam tulisan ini adalah penelitian kualitatif. Penelitian Kualitatif (Qualitative research) adalah suatu penelitian yang ditujukan untuk mendeskripsikan dan menganalisis fenomena, peristiwa, aktivitas sosial, sikap, kepercayaan, persepsi, pemikiran orang secara individual maupun kelomp Sok. Beberapa deskriptif digunakan untuk menemukan prinsip-prinsip dan penjelasan yang mengarah pada penyimpulan (Nana Syaodih Sukmadinata, 2010). Adapun tekhnik pengumpulan data dalam penelitian ini adalah observasi, dokumentasi dan wawancara (Sugiyono, 
2009). Kegiatan analisis dan pengumpulan data dilakukan interaktif dan merupakan siklus yang berulang-ulang, berlanjut secara terus-menerus dan saling menyusun sampai kegiatan akhir dalam penelitian siap dikerjakan. Model interaktif oleh Miles dan Huberman yakni pengumpulan data, penyajian data, reduksi data, dan verifikasi data.

\section{HASIL TEMUAN}

Peran Guru Dalam Mengembangkan Keterampilan Bahasa Siswa Melalui Kegiatan Literasi Di Kelas 04 SD Inpres Sangiang

Proses belajar-mengajar merupakan inti dari proses pendidikan secara keseluruhan dengan guru sebagai pemegang peranan utama. Peristiwa belajar mengajar banyak mengakar pada berbagai pendangan dan konsep, perwujudan proses belajar mengajar dapat terjadi dalam beberapa model. Pengertian proses belajar mengajar dikemukakan oleh Usman bahwa: Proses belajar-mengajar merupakan suatu proses yang mengandung serangkaian perbuatan guru dan siswa atas dasar hubungan timbal balik yang berlangsung dalam situasi edukatif untuk mencapai tujuan tertentu. Dari pengertian proses belajar mengajar yang telah diutarakan, maka kemudian melahirkan strategi dan penerapannya.

Peran Guru ialah dalam proses pendidikan merupakan ujung tombak bagi perwujudan kualitas pendidikan. Peran mulia itu merupakan aksi nyata yang dilakukan guru. Tampa guru siswa tidak akan bisa memiliki pengetahuan, dengan ini siswa akan memiliki ilmu tentang membaca dan menulis dan bisa mengembangkan bahasa dengan baik dan benar sesuai dengan kosa kata yang sebenarnya.

Lingkungan yang paling berpengaruh dalam pembentukan bahasa anak ialah sekolah, karena di dalamnya terjadi proses interaksi antara guru dan siswa dan siswa dengan teman sebaya nya yang dimana akan banyak menggunakan bahasa indonesia yang benar dan sekolah yang baik akan mengedepankan kenyamanan belajar bagi siswanya. Disamping itu guru memberikan dampak besar yang tidak hanya pada prestasi pendidik anak, tetapi juga pada sikap terhadap sekolah dan terhadap belajar pada umumnya, dalam upaya memunculkan, merangsang dan memupuk pertumbuhan kreativitas guru harus menata sikap dan falsafah mengajarnya. Oleh karena itu, peran guru sangat 
penting bagi peserta didik terlebih lagi dalam mengembangkan keterampilan bahasa peserta didik.

Kegiatan literasi merupakan kegiatan yang secara umum kegiatan membaca dan menulis untuk mengembangkan bahasa siswa supaya memiliki banyak perbendaharaan kata dalam bahasa indonesia dengan baik dan benar. Hal ini sebagaimana telah dijelaskan oleh ibu Rismah sebagai berikut:

Peran guru sangat penting karna dia memposisikan dirinya sebagai pandangan pertama didalam kelas dia bisa membuat siswa lebih memfokuskan siswa pada pembelajaran yang dia terapkan dan memberikan pembelajaran tematik yang secara berulang-ulang sampai siswa benar-benar bisa merealisasikan bahasa dengan baik dan benar " (Rismah, 2020). Kegiatan literasi merupakan kegiatan yang sangat membantu guru kelas melakukan pembelajaran tematik guna belajar membaca dan menulis di kelas 04 sd inpres sangiang dengan menggunakan buku paket siswa dapat membaca dengan berulang kali supaya siswa mudah memahaminya sesuai apa yg siswa baca akan siswa realisasikan melalui bahasa, lewat kegiatan literasi ini siswa mampu mengembangkan bahasanya dengan baik dan benar.dan disamping itu guru kelas juga tidak lupa buat pembelajaranya senyaman nyamanya supaya siswa dapat belajar dengan nyaman dan baik.dengan ini peran guru sangat lah urgen dalam mengembangkan keterampilan bahasa peserta didik. Pelajaran tematik khusunya bahasa indonesia di $\mathrm{Sd}$ inpres sangiang kecematan wera menggunakan berbagai macam metode pembelajaran seperti metode diskusi, metode ceramah, metode tanya jawab dan metode demostrasi. Untuk menjelaskan pembelajaran yang belum dipahami oleh siswa sampai mereka benar-benar memahaminnya melalui kegiatan literasi".

Selanjutnya Kepala sekolah SD Inpres Sangiang yakni bapak Azhar H. Abu Bakar mengatakan, bahwa Guru adalah madrasah kedua bagi anak-anak setelah orang tuanya, akan tetapi mesti guru hanya sebagai madrasyah kedua, orang tua anak-anak tetap menganggap kami sebagai orang yang akan mendidik, mengjar dan sumber ilmu bagi anakanak mereka dan hal ini terlihat dengan sikap orang tua murid yang sangat menghargai rutinitas kami di sekolah (Azhar, 2020).

Dengan demikian, peran guru SD Inpres Sangiang di kelas 04 sudah maksimal, hanya saja bagaimana mereka memberikan pembelajaran melalui kegiatan literasi senyaman nyamanya agar siswa bisa memperbanyak waktu untuk membaca dan menulis. Melalui cara ini 
siswa sangat diharapkan untuk lebih banyak menggunakan bahasa indonesia ketimbang bahasa daerahnya sendiri dan disini yang jadi orang pertama dalam mengembangkan bahasa tersebut ialah guru (Dian, 2020).

Pelaksanaan kegiatan pembelajaran di sekolah telah memenuhi standar dalam mengembangkan keterampilan membaca sebagai bagian dalam melestarikan budaya literasi di sekolah sebagaimana dijelaskan oleh ibu Rismah di bawah ini:

"Pada saat kegiatan literasi guru membagikan buku disetiap meja masing-masing siswa dan siswa akan menulisnya didalam buku sendiri lalu mereka satu persatu maju untuk membaca didepan berulang-ulang kali sampai mereka benar-benar bisa ini dilakukan salah satu untuk mengembangkan bahasa siswa, dengan sarana yang disediakan sekolah buku paket tematik maka siswa akan mudah membaca nya dengan suara yang keras dan lantang dan melakukan percakapan sesama temanya dan guru pula harus memperhatikan ruangan supaya pembelajaranya aman dan pada sa,at kegiatan literasi selalu lancar dan aman" (Rismah, 2020).

Ibu Rismah juga mengungkapkan bahwa siswa sangat aktif ketika disuruh untuk membaca di buku paket dan melakukan percakapan apa yang mereka baca dan tulis di buku paket, tetapi ketika siswa yang kurang lancar bacaan nya maka dia akan memilih diam dan tak berani untuk maju kedepan tapi dengan metode membaca satu-satu maka anakanak akan aktif dan berusah sebisa mungkin (Rismah, 2020).

\section{Cara Guru Untuk Mengembangkan Keterampilan Bahasa Siswa Melalui Kegiatan Literasi}

Pendidikan merupakan tanggung jawab bersama antara sekolah (guru), orangtua murid, masyarakat, dan pemerintah. Dengan demikian, semua pihak yang terkait harus senantiasa menjalani hubungan kerja sama dan dalam rangka mengembangkan keterampilan bahasa siswa yang baik bagi para murid. Interaksi semua pihak yang terkait akan mendorong murid untuk senantiasa melaksanakan tugasnya sebagai pelajar, yakni belajar dengan tekun dan bersemangat.

Guru ialah orang yang sudah memiliki banyak cara untuk menyampaikan pembelajaranya supaya sesuai dengan harapan yang diinginkanya, sesuai dengan kegiatan literasi guru banyak menggunakan 
cara atau metode supaya bisa mengembangkan bahasa siswa nya tersebut antara lain :

1. Guru menggunakan media literasi dengan buku aku dan dunia, dimana dalam buku menggunakan media kongkret berupa poster dan siswa diminta untuk menyimak bacaan guru lalu mengucapkan dengan lisan.

2. Guru menggunakan buku paket dengan ini siswa diberi buku paket masin-masing lalu menyuruhnya untuk membaca berulang-ulang setelah itu menyuruh masuk didepan untuk melakukan percakapan dengan teman lainya

3. Guru menggunakan bahasa lisan dan tulis yang benar dalam kegiatan literasi

4. Metode tanya jawab guru dengan siswa, guru yang akan bertanya sesuai buku yang mereka baca lalu siswa yang menjawabnya

5. Metode demostrasi melalui percakapan siswa dengan siswa lainya didepan kelas sehingga dengan ini guru mudah mengetahui sejauh mana mereka memiliki pengembangan bahasanya.

\section{Kendala Yang Dihadapi Guru Dalam Mengembangkan Keterampilan Bahasa Siswa Melalui Kegiatan Literasi Di Kelas 04 SD Inpres Sangiang.}

Menurut ibu penjelasan guru SD Inpres Sangiang, ada beberapa kendala yang dihadapi dalam kegiatan literasi yang berlangsung di kelas sebagai berikut:

1. Siswa yang kesulitan berbahasa indonesia dengan benar akan menggunakan bahasa daerah nya, disini guru terus membimbing dan memperhatikanya dan memberikan kasih sayang sepenuhnya dengan memberikan kata-kata motivasi supaya siswa ini semangat dalam pembelajaranya.

2. Dengan pembelajaran menggunakan buku paket disini guru sangat perhatian lebih terhadap siswa yang cara membaca nya masih dalam fase yang belum sempurna, dengan memnyuruhnya membaca berualng-ulang dan menyuruhnya untuk menulis apa yang ia baca maka disini dia akan mengembangkan bahasa nya sedikit demi sedikit 
3. Siswa yang masih minim dalam bahasa indonesia akan memilih diam ketika pembelajaran berlangsung.

4. Guru akan memberikan pengertian dalam arti dapat memahami pemikiran,perasaan dan perilaku siswa, dapat menempatkan diri dalam sitausi siswa dan melihat dari sudut pandang siswa.

5. Sarana misalnya seperti buku paket yang masih sedikit sehingga membuat siswa membaca dengan silih berganti pada sa,at pembelajaran berlangsung di kelas (Rismah, 2020).

Dengan banyak nya kendala-kendala diatas guru semakin banyak menguasai cara memberikan pembelajaran yang sangat baik sesuai dengan kekuarangan pada diri siswa. Guru akan berusaha sebisa mungkin supaya anak-anak bisa seperti yang diharapkanya, sebab ia yakin bahwa semua pasti bisa dan mampu dilaksanakan dengan sebaikbaik mungkin.

\section{SIMPULAN}

Peran guru sebagai mediator, fasilitator,pengelola kelas dan evaluator. ditinjau Secara keseluruhan perkembangan bahasa siswa di SD Inpres Sangiang lebih khusus dalam mata pelajaran bahasa Indonesia masih sangat kurang, hal ini ditandai dengan masih banyaknya siswa yang menggunakan bahasa daerah dalam kelas pada sa, at pembelajaran sedang berlangsung, dan siswa sebagian menggunakan bahasa Indonesia, artinya siswa masih perlu diberi pemebelajaran secara kontinyu penguatan literasi membaca dan menulis agar memiliki kemampuan memahami dan perbendaharaan tata bahasa Indonesia yang baik dan benar, dalam belajarnya lebih khusus dalam mata pelajaran pendidikan bahasa Indonesia.

Adapun kendala yang dihadapi guru dalam mengembangkan keterampilan bahasa siswa melalui kegiatan literasi di kelas 04 SD Inpres Sangiang adalah Sarana dan prasarana, perpustakan kurang memadai, Buku bacaan yang minim, terutama buku paket bahasa Indonesia sangat kurang, Kompetensi guru belum kompeten disebabkan kualifikasih pendidikan bukan S1 Bahasa Indonesia, Kekurangan guru mata pelajaran bahasa Indonesia yang berkualifikasi S1, dan Siswa yang malas membaca diperpustakaan 
DAFTAR PUSTAKA

Abdul Wachid B.S, \& Heru Kurniawan. 2013. Kemahiran Berbahasa Indonesia, Purwokerto, Kaldera Press.

An. 2018. Kamus Besar Bahasa Indonesia, (http;kbbi.web.id/terampil).

Azhar. 2020. Wawancara Dengan Kepala Sekolah SD Inpres Sangiang Kec. Wera Kab. Bima.

Dian. 2020. Wawancara Dengan Guru SD Inpres Sangiang Kec. Wera Kab.

Henry Guntur Tarigan. 2008. Menulis Sebagai Suatu Keterampilan Berbahasa, Bandung, Hak Cipta.

Nana Syaodih Sukmadinata. 2010. Metode Penelitian Pendidikan, Bandung, PT. Remaja Rosdakarya.

Nur Azizah. 2020. "Peran Guru Dalam Mengembangkan Bahasa Siswa Melalui Kegiatan Literasi' di SD Tara Salvia”, ( Skripsi )", UIN Syarif Hidayatulah Jakarta 2018,1, Dalam, Repoisitory. UINJKT.Ac.Id,Dspace.

Nursalim Ar. 2011. Pengantar Kemampuan Bahasa Indonesia Berbasis Kompetensi, Yogyakarta, Zanafa Publisihing.

Rismah. 2020. Wawancara Dengan Guru SD Inpres Sangiang Kec. Wera Kab. Bima.

Sardiman AM. 2004. Interaksi dan Motivasi Mengajar, Jakarta, Raja Grafindo Persada.

Sugiyono. 2009. Metode Penelitian Pendidikan Pendekatan Kuantitatif, Kualitatif, dan R\&D”, Bandung, Alfabeta.

St. Marwiyah. 2012. "Peran Guru Dalam Meningkatkan Mutu Pendidikan”. Dalam Jurnal Pendidikan, STAIN Palopo, Vol. 14 No. 1.

Suyanto dan Asep Jihad. 2013. Menjadi Guru Profesional: Startegi Meningkatkan Kualitas Guru di Era Global, Jakarta, Erlangga.

W. Gulo. 2004. Strategi Belajar Mengajar, Jakarta, Gramedia Widiasarana. 